\title{
Development of a Real-Time PCR Approach for the Specific Detection of Prunus mahaleb
}

\author{
Malcolm Burns*, Michael Walker, Timothy Wilkes, Laurie Hall, Kirstin Gray, Gavin Nixon \\ Science and Innovation, LGC Ltd., Teddington, England \\ Email: "malcolm.burns@lgcgroup.com
}

Received 9 July 2016; accepted 19 July 2016; published 22 July 2016

Copyright $(\underset{2015}{ }$ by authors and Scientific Research Publishing Inc.

This work is licensed under the Creative Commons Attribution-NonCommercial International License (CC

BY-NC).

http://creativecommons.org/licenses/by-nc/4.0/

(c) (i) () Open Access

\begin{abstract}
In 2015 a number of cumin spice products were withdrawn from the international market because of the suspected presence of almond, a known allergen from the Prunus genus. However, immunoassay results were unable to provide unequivocal evidence of the Prunus species present, because of significant cross-reactivity with other species within the Prunus genus. A novel real-time PCR assay was developed for the specific detection of Prunus mahaleb DNA, a species known to be capable of causing false positives in almond immunoassays. The assay was developed based on available DNA sequence information from the Internal Transcribed Spacer (ITS) region, and tested against representative species within the Prunus genus to ensure no cross-reactivity. Results showed that mahaleb DNA was detected in a cumin spice product subject to the earlier international recalls, which could not be unequivocally identified using immunoassay approaches alone. This short report details preliminary results from the application of this assay, and will be of interest to analytical laboratories involved in trace detection of ingredients in support of relevant food labelling legislation.
\end{abstract}

\section{Keywords}

Prunus, Almond, Mahaleb, Herbs and Spices, Real-Time PCR

\section{Introduction}

The UK Government Chemist has a role in safeguarding the quality of public science, and many of its duties are grounded in statute law such as the Food Safety Act 1990 [1]. In this capacity, the Government Chemist was contacted in February 2015 to investigate the alleged adulteration of a ground cumin sample, in which it had been reported that the presence of almond had been detected, posing an allergenic risk [2].

"Corresponding author.

How to cite this paper: Burns, M., Walker, M., Wilkes, T., Hall, L., Gray, K. and Nixon, G. (2016) Development of a Real-Time PCR Approach for the Specific Detection of Prunus mahaleb. Food and Nutrition Sciences, 7, 703-710.

http://dx.doi.org/10.4236/fns.2016.78071 
Random testing conducted by the Canadian Food Inspection Agency in October 2014 revealed almond protein in products containing cumin, a risk for people with these allergies [3]. This resulted in a widespread recall of cumin products and issuing of alerts on the EU Rapid Alerts System for Food and Feed [4]. In early 2015, the UK Food Standards Agency issued recalls on ground cumin and meals/dinner kits which contained cumin seasoning mixes, but the identity and source of the almond protein remained unanswered. A company subject to a recall of their cumin product later claimed another material in the supply chain, mahaleb, gave a positive reading for almond using test methods [5]. In April 2015, the Canadian Food Inspection Agency rescinded 25 previous product recalls, stating that new evidence had been provided that the almond allergen test kits showed significant cross-reactivity with another species of the Prunus genus, Prunus mahaleb [3]. This new evidence suggested that the undeclared presence of Prunus mahaleb in the ground cumin and cumin-containing products was the source of the ELISA positive results initially thought to be due to almond.

Almond (Prunus dulcis) is a member of the Prunus genus, which includes species of "stone fruits" capable of producing kernels, including apricot (Prunus armeniaca), cherry (Prunus avium), peach (Prunus persica), plum (Prunus domestica) and mahaleb (Prunus mahaleb), the latter of which little was known about in the UK until 2015. Mahaleb grows as a deciduous tree/large shrub, thought to be native to the Mediterranean region. The spice is often produced from the ground seed kernel of the species, and can be used to provide a sweet flavour when added to foods [6].

The primary approach for detection of almond protein is to use an immunoassay, but a number of commercially available kits for the detection of almond proteins are known to exhibit significant cross-reactivity with other members of the Prunus genus, notably apricot [7]. This was verified experimentally where a range of commercially available almond ELISA kits exhibited cross-reactivity with mahaleb and apricot kernels. Application of these kits to the recalled cumin product resulted in detection of generic Prunus peptides without providing any further information on the species identity. Published DNA assays for almond also exhibited cross-reactivity [8] and no real-time PCR assays were available for the specific detection of mahaleb DNA.

There was therefore a requirement to provide a more definitive analytical approach in order to specifically identify the Prunus species actually present in the cumin sample. Internal Transcribed Spacer (ITS) regions present in the plant genome have been recommended for use in possible DNA species barcoding, due to the high copy number rRNA genes they represent, coupled with the low evolutionary pressure on the DNA sequence, enabling highly conserved regions to be identified between members of the same genus [9]. This paper describes the development of a real-time PCR approach as a qualitative screening test for the specific detection of DNA from Prunus mahaleb. This assay was tested against a small set of representative Prunus species and cumin controls, and showed that Prunus mahaleb DNA was present in the cumin spice sample that was subject to the international recall.

\section{Materials and Methods}

\subsection{Referred Sample}

The sample referred to the Government Chemist for a definitive determination of which Prunus species was present was a ground sample labelled as "cumin", originating from a UK local authority food law sampling exercise in which a positive result for apparent almond had been obtained by ELISA.

\subsection{Control Material}

Organic cumin seeds, ground mahaleb and almond were purchased from online retailers; apricots and peaches were purchased from UK supermarket stores. Species identity of these control materials were independently confirmed using DNA sequencing (data not shown).

\subsection{DNA Extraction}

DNA from the referred cumin sample and control samples was extracted using a cethyltrimethylammonium bromide $(\mathrm{CTAB})$ approach as follows: samples were incubated at $65^{\circ} \mathrm{C}$ for at least 12 hours in a mixture of CTAB buffer (2\% [w/v] CTAB, $1.4 \mathrm{M} \mathrm{NaCl}, 20 \mathrm{mM}$ ethylenediaminetetraacetic acid, $100 \mathrm{mM} \mathrm{Tris-OH} / \mathrm{HCl})$, $\beta$-mercaptoethanol (0.2\% final concentration; Sigma), RNase A (100 mg/mL; Qiagen), Proteinase K (20 $\mathrm{mg} / \mathrm{mL}$; Qiagen) and nuclease-free water (Ambion). The DNA-CTAB complexes were stripped of lipids and 
carbohydrates following several centrifugation steps with chloroform (Sigma) before being precipitated using CTAB and 1.2 M NaCl. DNA pellets were washed with Ethanol (Fisher Scientific) and re-suspended in $75-100$ $\mu \mathrm{L}$ of nuclease-free water. Extracted DNA was quantified using a NanoDrop ND-1000 spectrophotometer (Thermo Fisher Scientific). All control materials were represented by two independent DNA extractions, whilst the referred cumin sample was represented by four independent DNA extractions.

\subsection{Sequence Comparisons}

A search of the available DNA sequence information was made in order to assess the feasibility of designing a novel real-time assay for the specific detection of mahaleb DNA. The DNA databases of the Barcode of Life Data System (BOLD) [10] and the National Center for Biotechnology Information (NCBI) GenBank [11] were accessed for publically available sequence data on the Prunus genus. At the time the searches were conducted (24th March 2015), 904 individual records of Prunus were available on the BOLD database, representing 188 different species within this genus, originating from 19 different countries. A search of the GenBank database revealed 236,565 nucleotide sequences for Prunus, of which 99,491 were derived from Prunus armeniaca, 1747 from Prunus dulcis, but only 49 from Prunus mahaleb.

Searches of the NCBI nucleotide and BOLD Systems DNA databases were also conducted to identify all publically available sequences of the background matrix of Cuminum cyminum (cumin). Available sequence information was then imported into BioEdit v7.1.11 [12] [13], and sequence alignment analysis performed using the inbuilt ClustalW Multiple Alignment function [14], based on standard parameters. The resultant aligned sequences from the different Prunus species were inspected to identify regions of sequence homology and polymorphism to make an objective decision on the design a specific real-time PCR assay for Prunus mahaleb (Figure 1).

\subsection{Real-Time PCR Assay}

A candidate ITS region was identified and a representative Prunus mahaleb sequence selected for subsequent assay design. The high copy number of the ITS region should also make the assay more suitable for trace detection of Prunus mahaleb DNA if the Prunus species was present at as a minority target. The selected sequence was imported into Primer Express 3.0.1 (Life Technologies, Paisley) and used as a template to design a “Taqman ${ }^{\circledR}$ Quantitation" type assay, based on standard software design parameters. A single candidate assay design was selected that showed primer binding within highly conserved regions for the Prunus genus, whilst the probe bound to an internal sequence that appeared specific for Prunus mahaleb (Table 1).

The primer set specificity was assessed using Primer-Basic Local Alignment Search Tool (Primer-BLAST) (NCBI) [15] against the broad Nucleotide database (based on standard parameters). Good primer set specificity was observed which was typically restricted to Prunus species. This in-silico sequence analyses indicated that the design was suitable for further experimental verification.

PCR was conducted using $900 \mathrm{nM}$ forward and reverse primers; $200 \mathrm{nM}$ probe; $2 \times$ TaqMan ${ }^{\circledR}$ Universal PCR Master Mix; DNA (maximum $25 \mathrm{ng}$ per reaction); all made up to a $25 \mu \mathrm{l} \mathrm{PCR}$ reaction. Real-time PCR thermal cycling conditions were: $50^{\circ} \mathrm{C} 2 \mathrm{~min} ; 95^{\circ} \mathrm{C}$ for $10 \mathrm{~min} ; 95^{\circ} \mathrm{C} 15 \mathrm{~s}$ and $60^{\circ} \mathrm{C}$ for $60 \mathrm{~s}$, repeated for 45 cycles. PCR was conducted using the ABI 7900 HT system (ThermoFisher).

\subsection{Experimental Design}

The mahaleb real-time PCR assay was tested across the range of control materials to assess the specificity of the

Table 1. Details of the putative LGC Prunus mahaleb specific real-time PCR assay.

\begin{tabular}{|c|c|c|c|c|c|c|}
\hline Assay Type & Target & Marker & Name & Sequence $\left(5^{\prime}-3^{\prime}\right)$ & Length (bp) & $\begin{array}{l}\text { Amplicon Size } \\
\text { (bp) }\end{array}$ \\
\hline \multirow{3}{*}{ qPCR } & \multirow{3}{*}{$\begin{array}{l}\text { Prunus } \\
\text { mahaleb }\end{array}$} & \multirow{3}{*}{ ITS } & PRU_ITS_FWD1 & TAGCAGAACGACCCGAGAACTAG & 23 & \multirow{3}{*}{$\sim 133$} \\
\hline & & & PRU_ITS_REV1 & CGCCGGTGTTCGTTTGTAC & 19 & \\
\hline & & & PRU ITS PROBE1 & TTCGCGCAACCGGCCCTTC & 19 & \\
\hline
\end{tabular}




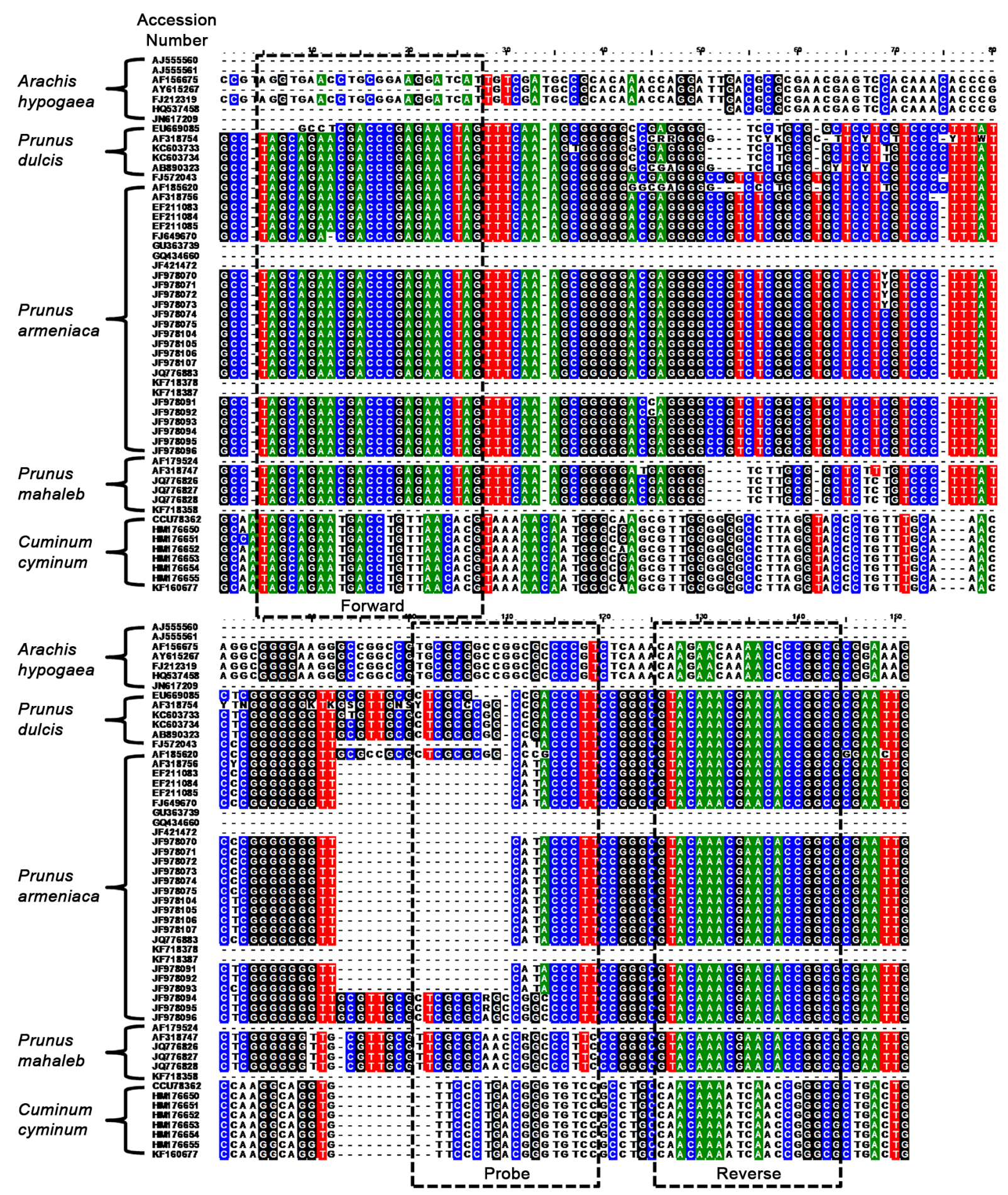

Figure 1. Assay map. Sequence alignment of a subset of Prunus species based on the ITS2 sequence, displaying primer and probe binding regions associated with the $P$. mahaleb specific real-time PCR assay. Sequence information imported into BioEdit v7.1.11 [12] [13], sequence alignment performed using ClustalW Multiple Alignment function [14].

assay, as well as applying it to the referred cumin sample. All control material was represented by two independent DNA extractions with 25 ng of DNA per PCR well. Four independent DNA extractions from the referred cumin sample were assessed, each extraction represented at $25 \mathrm{ng}$ and $2.5 \mathrm{ng}$ of DNA per PCR well. All samples were represented by a triplicate level of PCR replication within the experiment, and placed on a 96 well 
PCR plate. In addition to the DNA extracted from the control materials, a $1 \%$ mahaleb:cumin sample was prepared, based on a DNA:DNA volumetric dilution (a total of $25 \mathrm{ng}$ of template DNA per PCR well).

\section{Results and Discussion}

\subsection{Control Material}

Commercially available cultivars of cumin (Cuminum cyminum), mahaleb (Prunus mahaleb), almond (Prunus dulcis), peach (Prunus persica) and apricot (Prunus armeniaca), were sourced to verify experimentally the incidence of any cross-reactivity using the real-time PCR assay. Following DNA extraction, typical DNA yields of $150 \mathrm{ng} / \mu \mathrm{l}$ for the referred cumin sample and cumin control, at least $10 \mathrm{ng} / \mu \mathrm{l}$ for the Prunus control materials (apricot kernels, peach kernels, almond kernels, and mahaleb powder) were achieved. Species identity of the control materials were independently confirmed using generic PCR primers annealing to the ITS 2 and $r b c L$ regions of the chloroplast genome, DNA sequencing of the resultant PCR products followed by sequence confirmation on the Barcode Of Life Data System (data not shown).

\subsection{Experimental Results}

A real-time PCR assay was chosen as the model to develop the Prunus mahaleb assay with because of the improved selectivity afforded by the addition of a probe. Table 2 lists the quantification cycle $\left(\mathrm{C}_{\mathrm{q}}\right)$ values associated with applying the real-time PCR assay to DNA from the control materials, appropriate controls, and the referred cumin sample. Figure 2 shows the graphical interpretation of the real-time amplification plots associated with the results.

Detectable PCR responses were observed when the real-time PCR assay was applied to the mahaleb control material, as well as the referred cumin sample, and a $1 \%$ volumetric dilution of mahaleb DNA in a background of cumin DNA. No detectable response was observed in any of the other control materials, including apricot, peach, almond and cumin, or the negative controls of the extraction blanks and the PCR No Template Controls, indicating that there was no contamination at the DNA extraction phase, or the PCR template addition phase.

Figure 2 exhibits the $C_{q}$ values associated with the responses from the referred cumin sample which was assessed at template amounts of 25 and $2.5 \mathrm{ng}$ per PCR well. The difference in mean $\mathrm{C}_{\mathrm{q}}$ values between the two template concentrations was approximately 3.4 , translating to a theoretical 10 fold difference in template concentration. This matched the actual difference in template concentration exactly (i.e. 1:10), demonstrating the good quality of the DNA extracts with no observable inhibition in the referred cumin sample.

Table 2 and Figure 2 additionally illustrate the $C_{q}$ instrument response associated with the $1 \%$ mahaleb: cumin volumetric dilution and the referred cumin sample. Both samples were normalised to $25 \mathrm{ng}$ template

Table 2. Details of the putative LGC Prunus mahaleb specific real-time PCR assay. The $\mathrm{C}_{\mathrm{q}}$ standard deviations were derived from triplicate PCR measurements.

\begin{tabular}{ccc}
\hline Sample & Mean $\mathrm{C}_{\mathrm{q}}$ & $\mathrm{C}_{\mathrm{q}}$ standard deviation \\
\hline Almond & Undetermined & - \\
Apricot & Undetermined & - \\
Peach & Undetermined & - \\
Cumin & Undetermined & - \\
Template Control & Undetermined & - \\
PCR Noction Blanks & Undetermined & 0.06 \\
Mahaleb & 17.87 & 0.14 \\
1\% DNA:DNA mahaleb:cumin & 23.10 & 0.16 \\
Refrerred cumin sample (25 ng) & 30.26 & 0.30 \\
Referred cumin sample (2.5ng) & 33.69 & \\
\hline
\end{tabular}




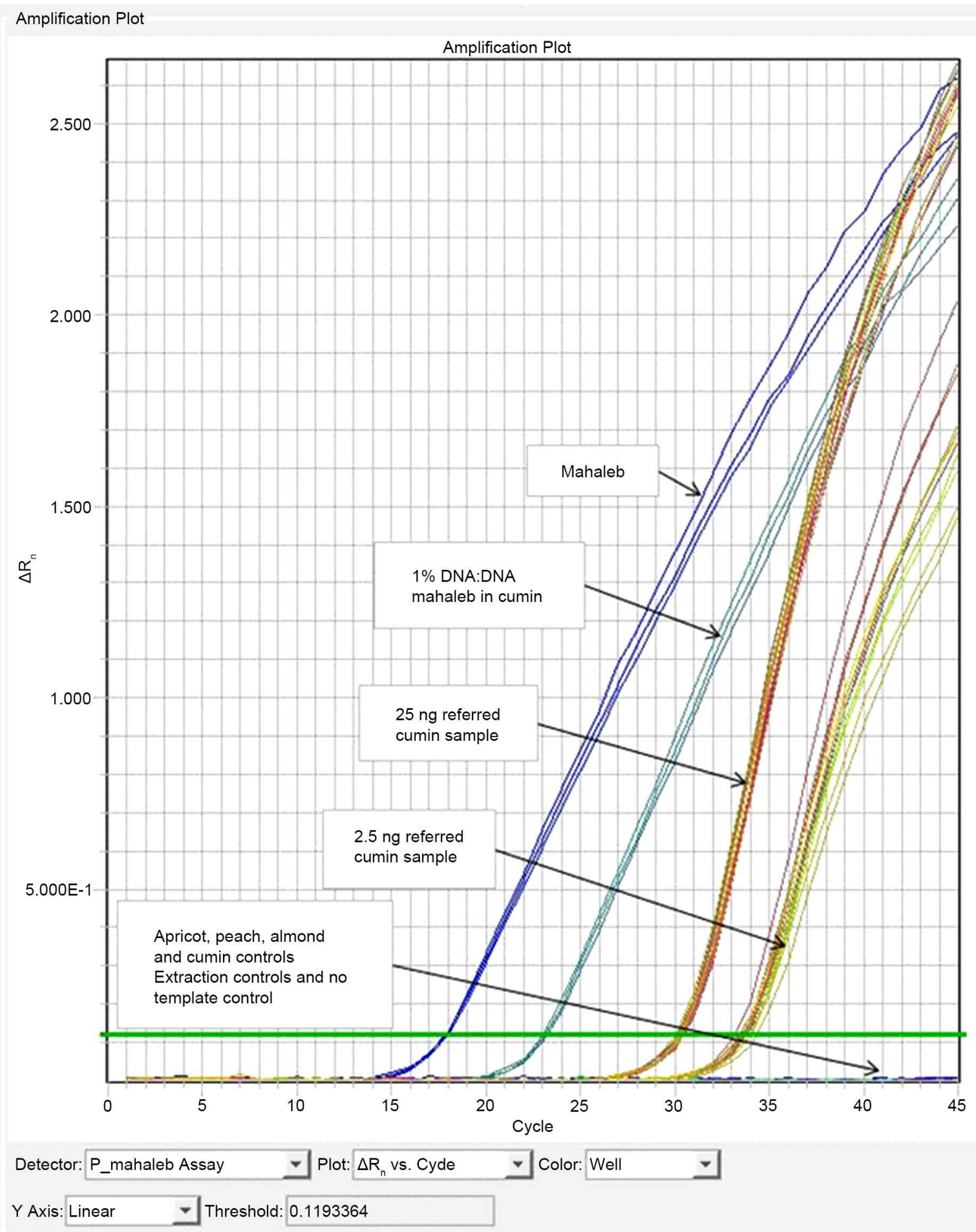

Figure 2. Real-time PCR amplification plot for all samples (cycle number is shown on the $\mathrm{x}$-axis and change in florescent intensity $\left(\Delta R_{n}\right)$ is shown on the $y$-axis; the green horizontal line indicates the threshold setting).

DNA per PCR well. A difference of around 7.2 $\mathrm{C}_{\mathrm{q}}$ values is seen between the two sets of samples. Assuming similar PCR efficiency between the samples and lack of any other Prunus DNA in the referred cumin sample itself, a $\mathrm{C}_{\mathrm{q}}$ difference of around 7.2 would indicate an approximate 150 fold difference in target template concentration between the referred cumin sample and the $1 \%(\mathrm{w} / \mathrm{w})$ control. This would infer the concentration of ma- 
haleb in the referred cumin sample could be less than $0.001 \%(\mathrm{w} / \mathrm{w})$ (less than $10 \mathrm{ppm}$ ). This further reinforced the applicability of using a real-time PCR approach for the detection of mahaleb, as even though the concentration may be less than $10 \mathrm{ppm}$ in the referred cumin sample itself, a detectable response has been repeatedly observed in all 24 PCR wells (representing four independent extractions at two dilution levels with three PCR replicates per extraction), all with good precision.

The real-time PCR assay primers have been designed to anneal to conserved regions present in species common to the Prunus genus thus DNA templates from other members of the Prunus genus will also amplify, but will not be detected as specificity to mahaleb has been conferred by the probe. However a positive result from the assay for Prunus mahaleb does not preclude the possible presence of DNA from almond, apricot and peach. For this reason, the $\mathrm{C}_{\mathrm{q}}$ based estimate of the level of mahaleb $(<0.001 \% \mathrm{w} / \mathrm{w})$ is on the assumption that no other Prunus species are present in the referred cumin sample which could compete as targets for the assay.

The real-time PCR assay described in this Short Report has only been tested on the control samples indicated. Whilst every effort was taken to ensure the control samples were representative of the specific species in question, there is a small likelihood that different cultivars within the same species may have small differences in their genetic makeup. There is an even smaller likelihood that such differences may manifest themselves as differences in the genetic code in the targeted ITS region, although this has a very low probability as the ITS region was chosen for its conserved and consistent sequence information between species within the Prunus genus. This is reinforced through the available DNA sequence information on the Prunus species (e.g. on NCBI GenBank and BOLD) which provides evidence of conserved DNA sequences within Prunus species accessions.

Given the good selectivity of the assay as demonstrated in the above results, there is therefore evidence to suggest that DNA extracted from the referred cumin sample generated a measurement response consistent with mahaleb being present, although it cannot be ruled out conclusively that other Prunus species were absent.

\section{Conclusions}

This short report describes a rapid response and preliminary findings from developing a novel real-time PCR assay as a qualitative screening test for the specific detection of Prunus mahaleb DNA, and its application to a spice sample suspected of being adulterated on the international market. The assay was developed using available DNA sequence information from the ITS region for members of the Prunus genus, and then tested experimentally on DNA extracted from a range of positive and negative control materials, inclusive of mahaleb material mixed with cumin. No detectable response from the assay was observed when it was applied to DNA from apricot, peach, almond and cumin, but repeatable positive responses were observed in the presence of DNA from mahaleb and a $1 \%$ mixture of mahaleb DNA in a background of cumin DNA. Commercially available ELISA immunoassay kits applied to the recalled cumin product detected the presence of peptides characteristic of the Prunus genus, but were unable to provide unequivocal identification of the Prunus species present because of significant cross-reactivity amongst closely related members of the Prunus genus.

At the time of the international recall of cumin products which were suspected of containing almond in 2015, commercially available immunoassay kits for almond were known to exhibit significant cross-reactivity with other species within the Prunus genus, notably apricot [7]. Additionally, no DNA assays were available that were specific to Prunus mahaleb [8]. This precluded positive and unequivocal identification of the mahaleb DNA which was present in the recalled cumin products. The development of the novel real-time PCR assay for the specific detection of mahaleb DNA, as described in this Short Report, will allow analytical laboratories to test for the presence of mahaleb DNA, potentially precluding costly international recalls of food products due to misidentification of ingredients. Given that authenticity of herbs and spices, and substitution affecting nut and seed powders, are recognised as prominent areas of concern by the UK Food Standards Agency in their Food Crime Annual Strategic Assessment 2016 [16], the issue of adulteration in this area is likely to remain of topical importance for the immediate future. This assay will be of interest to analytical laboratories involved in trace detection of ingredients in support of relevant EU labelling legislation on food and food stuffs.

\section{Acknowledgements}

The authors gratefully acknowledge funding through the UK Department for Business, Innovation \& Skills as part of the Government Chemist Programme 2014-2017. 


\section{References}

[1] Boley, N. (2016) Government Chemist Legislation: Annual Statement of Statutory Scope 2015. LGC/R/2016/439. https://www.gov.uk/government/publications/government-chemist-annual-statement-of-statutory-scope-2015--2

[2] Food Standards Agency (2015) Bart Ground Cumin Recalled. https://www.food.gov.uk/news-updates/news/2015/13512/bart-ground-cumin-recalled

[3] (2015) Canadian Food Inspection Agency_Agence canadienne d'inspection des ailments. http://www.inspection.gc.ca/about-the-cfia/newsroom/food-recall-warnings/complete-listing/2015-04-30/eng/1430432 $\underline{363404 / 1430432364107}$

[4] (2015) Europa Rapid Alert System for Food and Feed, RASFF, 2015. RASFF Portal, Reference 2015.0244 of 02/03/ 2015; Reference 2015.0370 of 26/03/2015. https://webgate.ec.europa.eu/rasff-window/portal/

[5] (2015) The Independent 05 March 2015 "Food Firm in 'Nuts-for-Spices' Row Blames False Test Results". http://www.independent.co.uk/life-style/food-and-drink/news/food-firm-in-nutsforspices-row-blames-false-test-results$10089275 . \mathrm{html}$

[6] (2011) US National Plant Germplasm System-Prunus mahaleb. https://npgsweb.ars-grin.gov/gringlobal/taxonomydetail.aspx?30034

[7] Walker, M.J., Burns, D.T., Elliott, C.T., Gowland, M.H. and Mills, E.N.C. (2016) Is Food Allergen Analysis Flawed? Health and Supply Chain Risks and a Proposed Framework to Address Urgent Analytical Needs. Analyst, 141, 24-35. http://dx.doi.org/10.1039/C5AN01457C

[8] Brežná, B., Šmíd, J., Costa, J., Radvanszky, J., Mafra, I. and Kuchta, T. (2015) In Silico and Experimental Evaluation of DNA-Based Detection Methods for the Ability to Discriminate Almond from Other Prunus Spp. Molecular and Cellular Probes, 29, 99-115. http://dx.doi.org/10.1016/j.mcp.2014.11.006

[9] Patwardhan, A., Ray, S. and Roy, A. (2014) Molecular Markers in Phylogenetic Studies-A Review. Phylogenetics \& Evolutionary Biology, 2, 1-9.

[10] Ratnasingham, S. and Hebert, P.D.N. (2007) BOLD: The Barcode of Life Data System. Molecular Ecology Notes. http://www.boldsystems.org/ www.barcodinglife.org

[11] (2016) National Center for Biotechnology Information, U.S. National Library of Medicine, 8600 Rockville Pike, Bethesda MD, 20894 USA. http://www.ncbi.nlm.nih.gov/

[12] Hall, T.A. (1999) BioEdit: A User-Friendly Biological Sequence Alignment Editor and Analysis Program for Windows 95/98/NT. Nucleic Acids Symposium Series, 41, 95-98.

[13] (2013) BioEdit v7.1.11. Tom Hall, Ibis Biosciences, An Abbott company, 2251 Faraday Avenue, Carlsbad, CA 92008, 760-476-3375. http://www.mbio.ncsu.edu/BioEdit/bioedit.html

[14] Thompson, J.D., Higgins, D.G. and Gibson, T.J. (1994) CLUSTAL W: Improving the Sensitivity of Progressive Multiple Sequence Alignment through Sequence Weighting, Position-Specific Gap Penalties and Weight Matrix Choice. Nucleic Acids Research, 22, 4673-4680. http://dx.doi.org/10.1093/nar/22.22.4673

[15] Ye, J., Coulouris, G., Zaretskaya, I., Cutcutache, I., Rozen, S. and Madden, T. (2012) Primer-BLAST: A Tool to Design Target-Specific Primers for Polymerase Chain Reaction. BMC Bioinformatics, 13, 134-145.

[16] (2016) Food Crime Annual Strategic Assessment-A 2016 Baseline, Food Standards Agency, Food Crime Unit, 2016. https://www.food.gov.uk/sites/default/files/fsa-food-crime-assessment-2016.pdf 


\section{Submit or recommend next manuscript to SCIRP and we will provide best service for you:}

Accepting pre-submission inquiries through Email, Facebook, LinkedIn, Twitter, etc.

A wide selection of journals (inclusive of 9 subjects, more than 200 journals)

Providing 24-hour high-quality service

User-friendly online submission system

Fair and swift peer-review system

Efficient typesetting and proofreading procedure

Display of the result of downloads and visits, as well as the number of cited articles

Maximum dissemination of your research work

Submit your manuscript at: http://papersubmission.scirp.org/ 